\title{
Alpine common property institutions under change: conditions for successful and unsuccessful collective action of alpine farmers in the Canton Grisons of Switzerland
}

Gabriela Landolt, PhD-Candidate, Institute of Social Anthropology Bern, Switzerland

Prof. Tobias Haller, Associate Professor, Institute of Social Anthropology Bern, Switzerland

\begin{abstract}
It is time to review the robust image of common property institutions in the management of summer pastures called "alps" in Switzerland created by Robert Netting and Elinor Ostrom and to show the challenges local institutions face today. Although the goal to protect and sustainably manage the summer pastures is stated in law since 1996 and summer pasturing payments have been bound to sustainability criteria since 2000 , local common property institutions increasingly struggle with maintaining their institutional arrangements especially regarding the collective maintenance work called "Gemeinwerk", which is necessary to allocate the common resource. Within the framework of Elinor Ostrom's design principles and Jean Ensminger's model of institutional change historical processes and the present situation of two local institutions to manage summer pastures in the Canton Grison (Graubünden) of Switzerland are described and discussed. The results show very different reactions to change: the reduction of the number of farmers, the increasing heterogeneity of their interests, shifts in ideology away from agricultural tradition and the decreasing bargaining power of the farmers, in one case, cause institutional collapse while in the other case the positive history of interaction, good leadership and a sufficient number of farmers to find new forms of organization open the doors for adaptation and institutional innovation.
\end{abstract}

Keywords summer pasture management; collective action; multi-level governance; institutional change

\section{INTRODUCTION}

Local institutions, which manage summer pastures in Switzerland, have been subject to well known research in the past. Between the 1970ies and the 1980ies Robert Netting (1972, 1976, and 1981) described the historical development of the common property institutions in Törbel (managing summer pastures and irrigation systems) and their sustainable adaptation to ecological and social conditions. This success story of collective action and example of sustainable use of common pool resources became later a cornerstone in Elinor Ostroms work "Governing the Commons" (1990) disapproving Garett Hardins "Tragedy of the Commons". Common property institutions to manage alps in Switzerland became known to be robust. Since Nettings observations, significant time has passed and conditions have changed. The Federal State and the cantons have increased their influence on the local natural resource management (Gerber et al. 2006). The common property institutions have faced several transitions and are now under pressure in the context of structural adjustments in the Swiss peasantry. The trend towards institutional instability in the management of alps is reflected by the increasing number of requests for assistance received by the agricultural training and advisory centre of the Canton Grisons (expressed as a concern by representatives). Collective action for managing the summer pastures, which Netting described as a natural process initiated by necessity in the case of Törbel, seems to become more difficult during structural change. As described by Netting (1981) or Stevenson (1991) collective action is regularly needed in order to allocate the common resource. The collective maintenance work to protect and improve the summer pastures is called "Gemeinwerk" and comprises activities such as the distribution of manure, repair work of alp infrastructure, or the clearing of the pastures from weed and stones. Hence, the ability to sustain the collective maintenance work is an indicator for collective action as well as for the sustainability of the resource use. In two 
village case studies (Sumvitg and Laax) in the Canton Grisons (Graubünden) where $60 \%$ of the 771 alps in the canton are property of the communes ${ }^{1}$ (community alps) and are used by alp associations (Alpgenossenschaften) (LBBZ 2007) the challenges for sustaining the collective maintenance work are illustrated. Sumvitg represents the communes that have managed to adapt to the economic, social and political changes and have found ways to take advantage of the new conditions. Laax represents the increasing number of communes that face collapsing alp associations and the task to find a way out of the difficult situation. To find the factors that explain the different reactions to change the two property systems are analyzed within Jean Ensminger's model of institutional change.

\section{Theoretical Framework}

The case of summer pasture management in Törbel is a core element of Elinor Ostroms work to prove successful common property resource management and the validity of the design principles. In this research the design Principles shall be used to show a revised picture of Swiss summer pasture management. The robustness of the two common property institutions under study will be evaluated and combined with Jean Ensminger's model of institutional change (1992). Already in earlier publications (Haller et al. 2010) the researchers have successfully used Jean Ensmingers framework as a theoretical instrument to examine processes and interactions, which help to explain present realities. Her model, rooted in the New Institutionalism, analyses institutional change induced by interaction between external (economic, demographic, social-political and technological) and internal factors, namely ideology, bargaining power, organisation and institution (Ensminger 1992, Haller and Merten 2008, Haller et al. 2010). Ensminger's framework to analyse institutional change provides a suitable basis to discuss under what conditions collective action takes place. Regarding external factors the role of the state and the market will be particularly assessed. Elinor Ostrom rightly asserts that "neither the state nor the market has been uniformly successful in solving common-pool resource problems" (Ostrom, 1990), still the importance of both state and market in common property management has not been contested but rather emphasized by many authors. Politics define the institutional framework that limits alternatives, structures incentives and the distribution of wealth (Bates 1994). The distribution of costs and benefits can be influenced by external interventions and increase or reduce the probability of collective action. External authorities can thus positively or negatively influence the probability and the achievements of local common property institutions (Bromley 1989; Haller et al. 2010; Poteete, Janssen and Ostrom 2010: 242f;). Policy has also a strong influence on economic institutions (Bromley 2006) but Ensminger further emphasises that not only political but also ecological, demographic, technological, and social changes affect the value of a resource and of one resource compared to another (change in relative prices). Changes in relative prices shift economic incentives, which can induce institutional change - but not necessarily (Ensminger 1992: 167). Regarding internal factors recent research increasingly recognizes the importance of social and power relations, of ideology and historical depth (Agrawal 2003; Haller et al. 2010; Haller and Merten 2008; Nightingale 2011; Poteete, Janssen and Ostrom 2010) and support Ensminger's earlier approach to focus on the history of social and power relations (bargaining power), ideology, heterogeneity of interests and transaction costs in explaining collective action and institutional change. Ideology can build trust, can define what is fair and what is unfair, or what is socially valued, and can be instrumentalized to legitimize institutional change or resistance. Heterogeneity of interests within the user group as well as the heterogeneity of interests and the unequal distribution of power between the user group

\footnotetext{
${ }^{1}$ The term „,commune“ is used referring to the political entity while the term „community“ is used referring to the social collectivity of habitants in a commune.
} 
and the community or society raise the transaction costs for collective action. However, the transaction costs can be lowered by good leadership, interaction and exchange of information (Ensminger 1992). On these assumptions we will discuss the conditions why in one village the people adapt successfully to change but not in the other and what the different reactions imply for the sustainable management of alpine cultural landscape.

\section{METHODS}

As Hodgson (2006) says, the only way to observe institutions is through manifested behaviour. In order to observe behaviour and to understand the emic view of actors involved in collective decision making participant observation was carried out on the two milk processing alpine farms in Laax and Sumvitg during the alp season 2010 (three months duration). Working on the alpine farms during this time enabled natural contact with the alp staff as well as with the farmers. The occasions when farmers were on the alp for taking care of their animals or for collective maintenance work were used to carry out informal interviews and focus group discussions (for example discussing about the impact of agrarian policies or changes in market prices in front of the alp stable). The contact with the farmers and the practical knowledge gained on the alp facilitated the semi-structured interviews that followed after the alp summer 2010. In one and a half to four hour interviews, questions about the development of the farm businesses (changes in the number and kind of animals, income sources and market prices, labour distribution, work processes and transhumance) on the one hand and the development of the collective institutions (oral and written regulations, decision making processes, and conflicts) on the other hand and why changes occurred (drivers of change) were conducted with the five farmers in Laax and ten farmers in Sumvitg. Interviews on local oral history were carried out with the eldest farmers and their wives of the villages (two in Sumvitg, one in Laax so far). Expert knowledge in alpine farming issues has been integrated through the close cooperation with a mixed expert team from the department of agriculture and the agricultural training and advisory centre of the Canton Grisons. During several meetings results from this research were presented, while the experts shared their experience and knowledge providing valuable inputs. As a result of this cooperation practical instruments to support local common property institutions shall be elaborated. Archival work has been initiated in both communes but will have to be done systematically together with a translator (Romanic-German) in the next research phase. For the next phase of this research (July - December 2011) participant observation will be conducted on the farms in the valley and quantitative data collected (questionnaire filled out by all farmers in Laax and Sumvitg).

\section{SUMMER PASTURES AS A COMMON POOL RESOURCE}

In accordance with the local variability of ecological conditions a high variety of common property institutions for summering animals on the alps have been developed (see Stevenson 1991). Those institutions were created long before the state started to exert influence. The origin of community alps is based on the so called "Talmarkgenossenschaften", a lose "community association" mostly defined by the natural limits of a valley. The common resources the valley provided were shared without restrictions (open access). With a growing number of residents and increasing cooperative activities (economic, military defence against other valleys or external powers) political and juridical entities were formed (Stevenson 1991: 115f; Weiss 1941: 167f). The community associations still persist in some areas until today (Canton Uri) while in the Canton Grisons the constitution of communes took place mainly between the $14^{\text {th }}$ and the $16^{\text {th }}$ century and replaced the community associations in their function to manage common property (Maissen 1978, Stevenson 1991: 117f). However the overall idea remained the same: The privately owned meadows in the valley were enlarged by 
the collectively used common pastures (state property). Only the collective use of the alpine pastures made the adaptation to the ecological variability and the patchiness of the natural resources (water and gras) as well as the share of costs (salaries for alp staff, material, maintenance work) possible (Bromley 1989: 15; Netting 1981). Hence, the use of summer pastures is integrated in a bigger system of natural resource government: it is linked to the private property of meadows by the rule that only as many animals are allowed to summer as can be fed through the winter with own fodder. In the Canton Grisons the vast majority of the community alps are used by alp associations. Alp associations are a collective of farmers that have to be either citizen (burger) or residents of the commune. While the communes define the broad legal framework, the alp associations maintain the right to organize themselves and to define and change regulations regarding the use of the alps. If written down in statutes and regulations and/or orally passed down from generation to generation as customary law regulations usually comprise the limits of the common resource and ownership, organs of the association, terms and duties of the board members, rules on access rights (who is allowed to use which grazing area, with what type and what number of animals during a defined time period), on decision making (voting rules), on the distribution of costs (who has to bear which costs, taxes paid to the owner), on sanctions in case of abusing rules, and on the collective maintenance work (Stevenson 1991: 122-131). Particularly in the case of the collective maintenance work not only the rules (hours per animal or type of work that has to be accomplished) determine the outcome (transaction costs, quality of work done) but the authority of the alp master in charge of coordinating and monitoring the work duties (Stevenson 1991: 129f; Weiss 1941: 250f).

\section{Collective maintenance work under pressure}

Rules restricting access to the common grazing grounds used to be the main concern. Since the late medieval times the number of animals summered on the common pastures was restricted to the number of animals a farmer was able to feed during the winter. This rule prevented overloading the pastures. In case that the demand for summering animals exceeded the local supply lottery rules assigning rotational rights were usually implemented and additional summering places arranged on foreign alps. Industrialization and the economic boom after the World Wars many farms initiated the structural adjustment process that leaded to a reduction of farm businesses from 13'111 in 1939 to 8'539 in 1969 in the Canton Grison (Weiss 1941: 198ff, Werthemann 1973:137f). As the number of farmers decreased, the concern of alp associations gradually shifted from restricting access towards the accomplishment of the collective maintenance work. For the 1960s Werthemann (1969: 130) describes a general loss of interest in alpine farming and especially in the work of maintaining the summer pastures due to the shrinking agricultural sector. In many cases earlier regulations regarding the collective maintenance work became a burden because the reduction of farmers caused a significant reduction of labour force while the workload and the number of summering cows remained the same (between 1958 and 1978 the number of cow owners sank from approximately 6'500 to approximately 3'900 according to Wertemann and Imboden 1982: 62). Collective maintenance work was done for free until the post-war period. But with the economic boom and other income alternatives the farmers were not willing anymore to work without monetary compensation. To resolve this problem more and more alp associations allowed the payment of compensation, high enough to pay farmers that worked additional hours or to pay third parties. This development was mainly driven by a change in relative prices: Federal state policies to support and protect the agrarian market (Federal Law on the support of agriculture 1893, Federal Law on the national food security in 1938, Federal Law on Agriculture 1951) could not prevent the value of labour from increasing by $250 \%$ while the price for milk increased only by $50 \%$ in the same time period. Summering (and farming in general) became more and more expensive (Werthemann and Imboden 1982: 62). 


\section{The dual role of the Federal State}

From the 1970s on, the farmers started to lobby for government financial support but had to wait until 1980 to get the first summer pasturing payments within the ordinance on the contributions to the agricultural production under difficult conditions (Werthemann and Imboden 1982: 62). The protectionist approach to sustain the agricultural sector soon collided with the principle of a liberal market economy promoted at the $8^{\text {th }}$ world trade round in Uruguay in 1986 and maximisation of production causing environmental problems collided with the raising ecological consciousness on the national and international level (global conferences on environmental issues in 1972 and 1992, Convention on Biological Diversity 1992). As a reaction mainly to the international pressure a fundamental agrarian reform took place in 1992. Direct payments became bound to ecological services, i.e. for maintaining cultural landscapes, while price guarantees were continuously reduced (BLW 2000). The development since the 1990ies shows a dual role of the state: The Federal State is obliged to open the markets and to make the agricultural sector more competitive (only possible through a reduction of farms and the expansion of remaining farms) while it is at the same time responsible for the conservation of the cultural landscapes, the biodiversity and the sustainable use of the alpine pastures. Regarding its later obligation, the former ordinance to support alpine farming was revised and replaced by the ordinance on summer pasturing payments (Sömmerungsbeitragsverordnung, SöBV) in 1999. The SöBV provides rules regarding an adapted stocking of the pastures in order to prevent overuse (limiting the number of animals in case of ecological damage), the protection of the pasture against scrub and forest encroachment, an adapted and biodiversity enhancing fertilization of the pastures, the control of problem plants and weeds and the maintenance of alp buildings and infrastructure. It should be noted that the regulations cover exactly the work traditionally done within the collective maintenance work. However, the implementation and monitoring is made difficult by the reliance of the cantons on the cooperation of the communes. Not all communes are eager to detect deficiencies, especially in the case of community alps. Furthermore, the management regulations are either difficult to control (fertilizing, feeding) or open to a wide margin of interpretation (natural regrowth, erosion) (Schulze 2011: 90). In order to see how the lower governmental levels react to the responsibility to control the regulations of the SöBV the legal framework of the Canton Grisons and the communes is presented next.

\section{The legal framework of summer pasture management}

On the cantonal level none of regulations directly express the duty to use the summer pastures sustainably. On the contrary, the Communal Law (Gemeindegesetz) of the Canton Grisons explicitly mentions in Article 41 that the collective maintenance work falls within the responsibility of the commune. Furthermore, the commune is allowed to outsource the task of managing the alps to private or public law corporate bodies (Article 63) providing the bases for the usual praxis of the communes to outsource the management of the alps to local alp associations under public law. The duty of the commune is to secure the use of the pastures for the local farmers (Article 30). The federal and cantonal law on spatial planning, and furthermore the directive plan (Richtplan) of the Canton Grisons do not support a general obligation to protect summer pastures. Rather they support the position that the preservation of alps shall depend on the services they provide. In case that the ecological gain of the renaturation of a pasture area exceeds negative effects (reduction of biodiversity, increase of natural hazard potential, loss of a valuable leisure area etc.) alpine farming shall not be an obligation. At the communal level there is in almost all cases (Laax is an exception, see below) a communal law regarding the management of alps and common pastures. 17 communal laws were analysed using Elinor Ostrom's design principles. It became clear that operational rules (DP 2), like the organisation of the collective maintenance work and the cost distribution (accounting system), as well as conflict resolution mechanisms (DP 6) are not 
mentioned by the communes. These tasks lay traditionally within the sovereignty of the alp associations and therefore mainly depend on their institutional setting. Regarding the institutional embeddedness (DP 8), cantons and communes are in charge of implementing Federal State laws, also the SöBV. But in none of the communal laws analysed concrete rules regarding the sustainable use of the alps and common pastures are mentioned and only in a few cases the adherence to higher laws in general was referred to. But also principles integrated in the communal laws, like the monitoring (DP 4), sanctioning (DP 5) and collective decision making highly depend on social and power relations between the alp association and the commune as well as within the alp association.

It becomes clear that despite existing rules on all governmental levels the sustainable use of the summer pastures comes down to local institutional arrangements established by the alp association and its social, political and economic environment. In the next section the two case studies will be presented with the scope to detect the major factors that support the institutional adaptation in one case and conflicts and resistance in the other case.

\section{THE VILLAGE CASE STUDIES: LAAX AND SUMVITG}

Being located in the same valley (Surselva) of the Canton Grisons the communes Laax and Sumvitg share a similar early history. Between the $14^{\text {th }}$ and $16^{\text {th }}$ century the alps of the Surselva were either in feudal hands by barons of the region or by the Disentis Monastry. The alps were given in fief to the communes for a yearly rent (Erblehenszins). The communes finally became proprietors by defending their rights against other communes (resulting in the settlement of boarders), and by trading and buying alp rights. Laax made its final payment to the baron of Rhäzuns in 1564. Sumvitg, even though the taxes were reduced to a symbolic amount, did its last payment in 1970 to the Disentis Monastery (Maissen 1978, Maissen 2000). Despite similarities in the constitution of the community alps the institutional development that followed turned out to be very different.

\section{Laax: Too small group size, heterogeneity of interests and lost bargaining power}

Laax is proprietor of the Alp Nagiens, which comprises 1102 ha of summer pastures providing grass to around 220 cows, heifers and calves (Maissen 1978: 287). While the limits between the Alp Nagiens and the neighbouring Alp Mughels from the commune Sagens were clarified and written down in the $19^{\text {th }}$ century as a result of heavy disputes the user rights within the community of Laax and the alp association stayed based on oral customary law (Maissen 1978: 81). An old foreign farmer (from a commune close by) belonging to a family that summers their cows in Laax since the time of reformation explained that the competition to summer animals on the Alp Nagiens had always been low due to the limited land of local farmers in the valley compared to the vast pastures on their alp. Hence, abundant pastures were available so that the formalization of rules has not been regarded as necessary. Until the end of the 1960ies a rotational system was in place to pass the position of the alp master from one member of the alp association to the next. This system was abolished in 1969 when the number of farmers diminished (27 in 1930, 18 in 1960, and 10 in 1977 according to Maissen 1978:287) and the position of the alp master as well as agriculture in general lost attraction due to the tourism boom that brought better income options to Laax. Tourism also increased land prices so that many farmers took the chance to make good money selling their land. During the early times of tourism all farmers described the relation with the tourist operator as a give and take on an equal base. Discussions were possible and the deals made with the tourism industry were perceived as fair. Still, the decreased number of farmers put pressure on the accomplishment of the collective maintenance work (increasing workload per farmer). Having abandoned the rotational system, the alp association could be stabilized though the 
long terms of two alp masters from 1970 to 2000 . Their ability to run the alp was able to hide the fact that the farmers became marginalized within their commune and that their bargaining power decreased continuously (the population of Laax increased from 467 habitants in 1960 to 1197 in 1985 enhancing the marginalization of the farmers and the last farmer left the community council in 1990 further disconnecting the farmers from communal politics). The alp masters were respected for their knowledge but also suspected to abuse their position for self-interests. Mistrust and conflicts rose until the alp association decided in 2000 to go back to the rotational system in order to distribute power more evenly. The negative effect was that the incentives to develop sustainable management structures and the commitment were low due to the short terms. In 2004 a rather inexperienced farmer had to take over the position of the alp master. He was missing the necessary traditional knowledge about rights and duties to run the alp so that he requested that customary law was written down. For the first time, regulations were written down by the five members remaining in the alp association (two young and three old farmers, all dairy farmers at that time) together with a representative of the commune and a cantonal agricultural advisor. Due to different views and opinions among the farmers the transaction costs to establish regulations were high and in the end only the standard rules were agreed on without considering any local specifics or local knowledge. The regulations could not prevent the failure of the rotational system. Under general approval one of the old alp masters from the period of 1970 to 2000 took over the position for three more years until 2008. In 2008 major changes happened, which made the institutional system collapse: Two of the younger farmers shifted from milk to meat production (mother cow husbandry), the community assembly of Laax decided to use one part of the cowshed of Alp Nagiens to open up a restaurant, the younger dairy farmer moved his cows to a neighbouring alp for summering due to the internal conflicts, and as a reaction to these changes the alp master resigned his position. Within one year everything changed as one of the younger mother cow farmers explained: "Sep and I changed to mother cow husbandry, the restaurant was built in the alp stable and Martin handed the position of the alp master over to the commune. Everything that was taken for granted suddenly disappeared. Usually there is something like an instruction manual telling you how the alp was managed so far. But nothing like that exists for the Alp Nagiens and that's why all knowledge, collected over centuries, has been lost overnight. It's a tricky situation as the ones that have the knowledge are not ready to share it but prefer to see the others fail". The fact that the farmers were not considered before agreeing to the building of the restaurant made them realize their marginalized position: "There is no tourism that allows discussions to find joint solutions. Here tourism dominates. 20 years ago one could share his opinion and was heard, but not so today. Decisions affecting the alpine pastures are taken by the community assembly without considering the farmers. And if you raise your voice during a community assembly you will be laughed at and ignored. Most of the farmers do not go there anymore". Resentments against the farmers are enhanced by a general change of ideology within the community. The subsidies and construction privileges (the Federal Law on Spatial Planning allows farmers to construct stables and residential houses in the agricultural zone) farmers receive from the Federal State are not perceived as justified and fair compared to the work the farmers do (mentioned by several members of the local government). With no leader and in a decision making environment where there is nothing to win and not much to lose none of the farmers wanted to take over the position of the alp master. In the end the commune as the owner of the alp had to find a solution. The responsibility fell into the domain of the head of department for tourism and agriculture. He was not a farmer and had no experience in alpine farming and in managing an alp. Furthermore, he could not count on the support of the farmers as he was made responsible for the predicament. The only way to strengthen his position was to ask the agricultural training and advisory centre of the Canton Grisons for assistance. But suggestions made by the cantonal agricultural advisor were per se not accepted by the farmers, mainly, as it turned 
out later, because they collided with customary law and were not well enough explained to the farmers. In despite of the resistance by the farmers changes were made inter alia in the accounting system. The lack of transparency of the new system raised doubts about the fairness of the distribution of costs and benefits adding to the institutional instability. The result of the alp summers of 2009 and 2010 were high transaction costs regarding the organization and monitoring of the collective maintenance work, due to a lack of leadership and traditional knowledge, and unresolved conflicts.

\section{Sumvitg: History of positive interactions and good leadership}

The case of Sumvitg illustrates a different situation. 5500 ha of the territory of Sumvitg are common pastures comprising not only alpine pastures but also common pastures in the valley (Heimweiden). There are seven alps providing pastures for around 1200 animals: traditionally two of them are cow alps, four are young cattle alps and one is a sheep alp. The historical process of the legalization of property relations ended in the first law on pasture and alp management already in 1805. The laws defined the limits of the different alps and common pasture areas, when, by what type of animals, and for how much taxes and Gemeinwerk the local farmers were allowed to use them. The four young cattle alps were managed by the Commune. The head of the department of agriculture employed herders, selected a farmer as alp master and did the final accounting. The two cow alps, named Naustgel and Glivers, were already organized in alp associations and took care of all tasks by themselves. The two alp associations had their own statutes but no regulations. Every ten years the communal law was revised by a commission of farmers and changes had to be implemented by the alp associations. The president of the alp association of Alp Naustgel explained that the absence of regulations (operational rules) caused difficulties in the enforcement of the communal law especially when rules changed. Also the statutes were often not adapted to changes. The major issue that had to be discussed every ten years was how to distribute the animals among the alps. The regularly excess of animals made it necessary to rent additional summering places on neighbouring alps (until today Sumvitg has summering rights on alps in the neighbouring communes Trun and Russein) and to install a lottery rotational system that selects the farmers which had to give their cattle to the foreign alps. Each alp association had to bargain individually with the commune council in order to address their needs. An old farmer who was part of the commune council in the 1950ies described the discussion about the instalment of a water supply system on the Alp Naustgel as a real battle between him (as farmer and member of the commune council) and the rest of the commune council. Proudly he added that after years of persistent efforts he finally brought the matter through. The environment for change slowly improved when the Federal State started to subsidize alp renovations, the construction of modern alp infrastructure and the summering of livestock. Besides the new options for financial support from the Federal State and the canton also the difficulty to find alp staff for this hard and badly paid work (compared to the easier and much better paid jobs available in the rising industrial sector at that time) leaded to the construction of a new alp stable in 1984. In the 1990ies changes started to speed up, the number of farmers decreased (from 142 farmers in 1955 to 36 farmers in 1998, according to Maissen 2000: 28) and the dairy cows were replaced more and more by mother cows and young cattle. The ten year revision turned out to be inert in the light of the fast changing world. In 1995 the second cow alp Glivers lost the permission to produce cheese because of antiquated production structures that didn't comply with federal and cantonal guidelines. Because longer term solutions had to be found (to renovate or transform the cow alp to a mother cow alp) and temporary solutions had to be put in place in the meantime, the law was only revised for a term of five instead of ten years. Shortly after the community assembly decided to renovate Alp Glivers and to keep it as a cow alp. The renovation took place in 1999. In the year 2000 the alp commission was again asked to revise the alp and pasture law of the commune. The commune asked three 
young farmers in the commission known for their ability to find innovative and acceptable solutions. It happened that in the same year the decree on summering pasture payments changed in a decisive way: It was allowed now to pay the subsidies directly to corporations under public law giving them more autonomy in the financial management of the alps. Inspired by the new policy regarding the financial options and aiming at operational independence in order to react more rapidly to change (particularly to the continuing trend to shift from dairy cows to mother cows), the alp commission elaborated the idea to unify all seven alps (organized as alp associations) under the roof of an alp cooperative. As a public law cooperative they were able to lease all common pastures (in the valley and on the alps) from the Commune for a yearly rent. Although there are still 28 farmers in the cooperative, the loss of social status and the tendency of losing bargaining power in the community is also noticed in Sumvitg and was one of the reasons to create the cooperative, the president of the cooperative said. To win over the farmers to support the idea, this was a process of ups and downs: "At first, the level of consent was high, but then, when uncertainties rose only a narrow majority was reached, but when all saw that the goal is near and benefits foreseeable the support increased again". An old farmer further explained the success of collective action pointing out that "we have a few intelligent young farmers, with a good education, which steer the boat. As long as the others jump on a lot can be achieved". At the commune the idea was welcomed. The fact is that the management of the alps require a high workload and hence costs for the commune. A lease contract was elaborated and implemented in the same year. Within the new institutional structure decisions are taken on two levels: at the general assembly on the level of the alp associations (now having statutes and regulations) and at the general assembly on the level of the alp cooperative. Only in rare cases, when fundamental changes or higher investments shall be made then the decision has to be taken by the general assembly of the whole community. But also in this case the president of the cooperative is not worried: "We only bring absolutely necessary, well thought through, and broadly supported requests before the community assembly. If we organize ourselves well, bring our children and grand parents to vote for the cause, we will have the majority and win". Furthermore the farmers are still well represented in the community council so that lobbying for the interests of the farmers, and the communication and exchange of information between the local institutions and the communal political level is given. The creation of the cooperative in the year 2000 enabled the farmers to change their rules, especially the distribution of animals among the alps, every year. The high institutional flexibility, the independence from the commune and the increased bargaining power in the community through the more centralized organisation (speaking with one voice) were noticed as the major benefits of the new institutional structure.

\section{DISCUSSION AND CONCLUSION}

Multi-level governance has not yet explicitly been an issue in the discussion of summer pastures management in Switzerland (but for Swiss environmental and nature protection policies see Gerber et al. 2006). However, now that the Federal State is interested in protecting the alpine pastures through concrete rules defined in the SöBV and that the agricultural training and advisory centre of the Canton Grisons is asked to assist in crises management regarding community alps, the management of summer pastures becomes a concern of higher governmental levels. The analysis of the legal framework regarding alp management shows that the goal of the Federal State to use the summer pastures sustainably is not explicitly supported by lower level regulations. Hence, the sustainable management of alpine cultural landscape with its ecological multifunctionality depends in the end on the robustness of local common property institutions and their ability to sustain the collective maintenance work. The comparison of the two case studies by the means of Elinor Ostrom's 
design principles proves that not all common property institutions are able to keep up the institutional robustness to adapt to changing conditions (see table 1 below).

Table 1 Evaluation of Ostrom's 8 Design Priciples

\begin{tabular}{ll}
\hline & Laax \\
\hline $\begin{array}{l}\text { Clearly defined } \\
\text { boundaries }\end{array}$ & $\begin{array}{l}\text { Well defined by the limits of the } \\
\text { commune and maps drawn by the } \\
\text { canton.The user group is defined } \\
\text { through cantonal law and local } \\
\text { customary law. Statutes are missing } \\
\text { that define the organisational structure } \\
\text { and the legal nature of the association. }\end{array}$ \\
& $\begin{array}{l}\text { The number of animals and the time } \\
\text { frame to use the pastures is limited } \\
\text { according to local ecological } \\
\text { conditions. The distribution of costs } \\
\text { equivalence between } \\
\text { benefits and costs }\end{array}$ \\
& $\begin{array}{l}\text { and benefits are not transparent, not } \\
\text { clearly defined and perceived as unfair } \\
\text { by all parties involved. Allocation }\end{array}$ \\
& rules are not adapted to the local \\
conditions.
\end{tabular}

3. Collective-choice There are no participative platforms agreements for collective decision making, neither within the alp association nor within the community. Collective-choice is hampered by strong self-interests.

4. Monitoring

Monitoring is insufficient because the alp master from the commune lacks authority and the necessary knowledge.

5. Graduated sanctions

6. Conflict resolution mechanisms

7. Minimal recognition of rights to organize

8. Nested enterprises
Sanctions (fines) are mentioned in the regulations but have not been enforced due to the lack of legitimacy of the rules and no authority.

The commune tried to mediate but due to high transaction costs and little results the commune asked a cantonal agricultural advisor for assistance, but external mediation is not accepted by the farmers and conflicts persist.

The right is there but not actively used by the farmers.

There is no communal law regarding the alp and customary law is not supported enough to be effective.

\section{Sumvitg}

Well defined by the limits of the commune and maps drawn by the canton. The user group is defined by communal law. Statutes of the alp associations are available.

The number of animals and the time frame to use the pastures is limited according to local ecological conditions. The distribution of costs and benefits are clarified in the statutes. Allocation rules are adapted to local conditions.

There are two platforms for collective decision making within the cooperative and a lobbying platform in the local government (three farmers in the local government).

The monitoring is supported by social control, the authority of the alp master, the board of the alp association and the cooperative.

Sanctions are in place (fines) but not yet enforced due to the high authority of the alp master (issuing cautions) and social pressure.

The board of the alp association is the first contact to resolve conflicts. So far conflicts could be resolved by internal mediation.

Self-organisation is welcomed by the Commune and is pro-actively used by the farmers.

The alp associations are embedded in the cooperative as well as in the institutional setting of the Commune.

In order to explain institutional change and the success or failure of collective action Ensminger's model of institutional change and the approach of New Institutional Economics provided a suitable framework. The common property institutions in Laax and Sumvitg both feel the pressure induced by changing relative prices and structural adjustments (decreased number of farmers, high workload for collective maintenance work, decreasing social status and bargaining power) but the history of interactions, the communication and distribution of information, the heterogeneity of interests, the group size, ideology and power relations let them react differently to change. One difference between the two villages is the influence of 
tourism. The boom in the tourism sector in Laax made land prices rise so that many farmers sold their land for construction of tourist infrastructure, ski slopes, or holiday houses. Hence, the number of farmers and the importance of agriculture for the community decreased much faster in Laax than in Sumvitg where tourism is absent and the number of habitants has always been stable. The size and heterogeneity of the user groups can be explained by these developments: In Laax, the small group of members of the alp association and the heterogeneity of interests caused by specialization and generational conflicts increase the transaction costs to get organized and to homogenise interests in order to defend against other interest groups. In the case of Sumvitg on the other hand the number of local farmers is still relatively high and the user group consists entirely of local farmers. Still, the heterogenization of interests through specialization of the farms can also be observed in Sumvitg. The important difference though is that heterogeneity is reduced through interaction and communication (general assemblies in the alp association and the cooperative during the collective maintenance work, the alp festivity and the joint dinner with the whole cooperative together with all alp staff to celebrate the end of the alp season). In Laax the heterogeneity of interests are enhanced by the unequal distribution of information and knowledge, the rare occasions of interaction (due to specialization and individualization) and the loss of bargaining power (tourism does not discuss anymore). Even the collective maintenance work or the traditional festivity on the alp are not places to meet anymore because the collective maintenance work is split between the conflicting parties or is done individually and the alp festivity has become a public and tourist event boycotted by the farmers. Besides social interaction the aspect of leadership plays a crucial role in reducing transaction costs for collective action. In the case of Laax leadership is characterized by local knowledge. The strong leadership by the two alp masters between 1970 and 2000 reduced the costs to run the alp and made it possible to ignore changing conditions. On the other hand the one man leadership model is also responsible for the uneven distribution of knowledge that prevented a participatory decision making process and collective action at the moment when the leadership broke down. While in Laax the role of leadership is ambiguous, leadership in Sumvitg is only positively charged and the main trigger for successful collective action. Leadership is linked to middle aged farmers with knowledge based on experience, good education, communication skills and future-oriented thinking. The leaders that initiated the idea of the cooperative have been well known already as respected leaders of the alp associations and were part of earlier commissions ordered by the commune to revise communal law regarding the alp management. Also, the farmers were used to the process of changing rules because of the long history of revising communal law. Collective action was further supported by the perspective of future advantages and the high probability of success. Unlike in Laax, the farmers in Sumvitg still have enough bargaining power to defend their interests in the community. In Laax the farmers know that their future will be mainly determined by politics and other interest groups and hence future perspectives do not provide incentives for collective action. Beside collective action, individual action and decision making has to be considered. Only if Federal State subsidies keep the summering of animals economically viable will the individuals be interested in using the alps and in maintaining common property institutions in order to facilitate their use. Hence, sufficient direct payments are a precondition for the conservation of alpine cultural landscapes but no guarantee for their sustainable use as effective controlling mechanisms at higher government levels are missing. State interference to strengthen the monitoring and control of the SöBV would violate the autonomy of the cantons and the cantons will not have the means to bear the costs of rigorous controlling. This leads to the conclusion that the challenge of the federal state, the cantons and the communes will be to find the right instruments to strengthen the robustness of local common property institutions without interfering with the sovereignty of the communes or the right to organize. 


\section{References}

Agrawal, A. (2003). „Sustainable governance of common-pool resources: context, methods, and politics“. Annual Review of Anthropology $32: 243-262$.

Bates, R. 1994. Social dilemmas and rational individuals. In Anthropology and Institutional Economics, ed. J. M. Acheson, 43-46. Lanham, MD: University Press of America.

BLW (Bundesamt für Landwirtschaft) (2000). Agrarbericht 2000. BLW, Bern.

LBBZ Plantahof (2007). Situationsbericht Alpwirtschaft im Kanton Graubünden 2001 - 2005. Im Auftrag des Amtes für Landwirtschaft und Geoinformation. Fact Sheet Kanton. Juni 2007.

Bromley, D.W. (1989). Economic interests and institutions : the conceptual foundations of public policy. Basil Blackwell, New York.

Bromley, D.W. (2006). Sufficient reason : volitional pragmatism and the meaning of economic institutions. Princeton University Press, Princeton.

Ensminger, J. (1992). Making a Market. The Institutional Transformation of an African Society. Cambridge University Press, Cambridge.

Gerber et al. (2006). The contribution of CPR institutions implementing Swiss environmental and nature protection policies. IASCP Europe Regional Meeting, Brescia, Italy.

Haller and Merten (2008). "We are Zambians - don't tell us how to fish!" Institutional Change, Power Relations and Conflicts in the Kafue Flats Fisheries in Zambia. In: Human Ecology 36(5): 699-715.

Haller et al. (2010). Disputing the Floodplains: Institutional Change and the Politics of Resource Management in African Wetlands. African Social Studies Series. Leiden: Brill.

Hardin, G. (1968). The tragedy of the commons. Science162 : 1243-1248.

Hodgson, Geoffrey M. (2006). „What are institutions? “ Journal of Economic Issues 40/1: 1-25.

Maissen, A. (1978). Laax - eine Bündner Gemeinde : Studien zu ihrer Geschichte, Sprache, Kultur und zur touristischen Entwicklung : 550 Jahre Loskaufbrief der Freien von Laax 1428-1978. Stiftung "Pro Laax": Laax.

Maissen, A. (2000). Somvix: eine kulturhistorische Darstellung Gemeinde Sumvitg. Gemeinde Sumvitg, Sumvitg.

Netting, Robert McC (1981). Balancing on an alp: ecological change and continuity in a Swiss mountain community. Cambridge University Press, Cambridge.

Netting, Robert McC (1976). ,What Alpine Peasants Have in Common : Observations on Communal Tenure in a Swiss Village“. Human Ecology, Vol. 4, No.2, 1976.

Netting, Robert McC (1972). „Of Men and Meadows: Strategies of Alpine Land Use“. Anthropological Quarterly, 45:3 (1972; July) p. 132.

Nightingale, A. (2011). „Beyond Design Principles: Subjectivity, Emotion, and the (Ir)Rational Commons“. Society and Natural Resources $24: 119-132$.

Ostrom, E. (1990). Governing the Commons. The Evolution of Instiuttions for Collective Action. Cambridge University Press, Cambridge.

Poteete, A. R., Janssen, M. A., Ostrom E. (2010). Working Together: Collective Action, the Commons, and Multiple Methods in Practice. Princeton University Press, Princeton.

Schulz T. (2011). Ex-post Wirkungsanalyse und Vollzugsanalyse der Sömmerungsbeitragsverordnung (SöBV). Technischer Bericht aus dem AlpFUTUR-Teilprojekt 13 ,Politikanalyse-Evaluation bestehender und alternativer Steuerungsinstrumente für das Sömmerungsgebiet" [published online March 2011] available from World Wide Web http://www.wsl.ch/publikationen/pdf/10914.pdf. Eidgenössische Forschungsanstalt für Wald, Schnee und Landschaft WSL, Birmensdorf.

Stevenson, G.G. (1991). Common property economics. A general Theory and Land Use Applications. Cambridge University Press, Cambridge.

Werthemann, A. (1969). Schweizerischer Alpkataster. Kanton Graubünden. Teil 1. Abteilung für Landwirtschaft EVD, Bern.

Werthemann, A. (1973). Schweizerischer Alpkataster. Kanton Grubünden. Teil 2. Abteilung für Landwirtschaft des EVD, Bern. 
Werthemann, A., Imboden, A. (1982). Die Alp- und Weidewirtschaft in der Schweiz. Zusammenfassung der Alpkatastererhebungen. Bundesamt für Landwirtschaft, BLW, Bern.

Weiss, R. (1942). Das Alpwesen Graubündens. Wirtschaft, Sachkultur, Recht, Älplerarbeit und Älplerleben. Reprint der Originalausgabe von 1992. Octopus-Verlag, Chur. 